\title{
PENGARUH FATHERLESS TERHADAP KARAKTER ANAK DALAM PRESPEKTIF ISLAM
}

\author{
Siti Maryam Munjiat \\ Fakultas Ilmu Tarbiyah dan Keguruan \\ Institut Agama IslamNegeri Syekh Nurjati Cirebon \\ email: Sitimaryammunjiat@gmail.com
}

\begin{abstract}
Abstrak
Menjadi seorang ayah kebanggaan bagi setiap pria, bahkan menjadi ayah sebuah anugerah yang tak terkira harganya. Kebahagian dalam hidup akan semakin lengkap dengan status baru menjadi seorang ayah untuk anakanaknya. Oleh karenanya, keetiadaan posisi ayah berdampak pada perkembangan baik fisik dan psikis sang anak, seperti larut dalam kesedihan bahkan mengalami ketertinggalan mental. Dalam mengkaji persoalan di atas, penulis menggunakan metode kajian pustaka, yaitu metode yang menggunakan kajian bacaan (literasi) sehingga dapat diperoleh hasil bahwa, ketiadaan peran ayah baik secara fisik Maupun psikis sangat berdampak dan berperan penting pada perkembangan anak. Tanpa peran ayah anak akan minder serta sulit adaptasi dengan dunia luar. Selain itu, kematangan psikologis anak tumbuh melambat dan cenderung kekanak-kanakan. Bahkan, anak cenderung lari dari masalah dan emosional saat menghadapi masalah. Dan, anak kurang bisa mengambil keputusan atau ragu-ragu dalam banyak situasi yang membutuhkan keputusan cepat dan tegas.
\end{abstract}

Kata Kunci: Fatherles, Perkembangan Anak, Peran Ayah dalam Islam 


\section{A. Pendahuluan}

Masalah terbesar di dunia saat ini adalah bukan masalah ekonomi atau pun sosial, tapi masalah keluarga. Dunia sedang kehilangan seorang ayah. Fatherless generation, generasi tanpa ayah. Kehilangan kasih seorang ayah walaupun kelihatannya tidak ada masalah, tapi itu merupakan masalah yang amat besar. Karena kasih sayang dari seorang ayah merupakan sumber rasa aman bagi seorang anak di dalam menghadapi perjuangan hidup yang harus dijalaninya kelak. Kalau kita banyak menemukan orang dengan sifat yang mudah putus asa, egois, kejam, dll., kebanyakan mereka pada waktu anak-anak mengalami kekurangan kasih sayang dari seorang ayah. ${ }^{1}$

Dunia anak yang melingkupinya adalah selalu perempuan, terutama yang terlibat dalam pengasuhan anak secara rutin. Padahal keluarga yang kehilangan ayah (fatherless families) tidak hanya mengakibatkan marjinalisasi sosial, tetapi juga dianggap berisiko bagi terjadinya perkembangan penyimpangan karena ketidakhadiran figur laki-laki yang kuat yang mana anak laki-laki dapat "mengidentifikasi" dirinya.

O'Hagan dan Dillenburgre (1995) mengeksplorasi bagaimana ketidakhadiran - dan kadangkala penghindaran-laki-laki dalam intervensi kerja sosial kemudian mempatologisasi perempuan (dan sekaligus mengeluarkan lakilaki). Terlepas penggambaran media tentang "laki-laki baru" yang menggendong bayi sebagai indikasi keintiman yang baru ditemukan, namun penggambaran yang dominan tentang pengasuhan anak masih menganggap "orangtua" sama dengan "ibu". 2

Sejak industrialisasi mendorong pertumbuhan keluarga kecil, tanggung jawab terhadap anak hanya dibebankan kepada seorang ibu. Keberhasilan dan kegagalan pengasuhan yang dilakukan seorang ibu merupakan topik perhatian yang menarik setidaknya karena jika seorang ibu "gagal", maka negara diharapkan turut berperan dan mendanai jasa-jasa layanan, termasuk "pengasuhan". Bantuan kesejahteraan selalu dibayar dengan peningkatan penyelidikan yang cermat. Bantuan tersebut diikuti dengan harapan dari aparatur negara yang mengonstruksi ibu sebagai orang yang bukan hanya bertanggung jawab terhadap kesejahteraan anak-anak saat ini, tetapi juga untuk perilakuperilaku moral mereka di masa depan. ${ }^{3}$

Secara tidak sadar kita sering mengaitkan penjagaan bayi dengan ibu dan wanita, tetapi sebenarnya peranan ayah juga tidak kalah pentingnya. Keluarga yang bahagia dan sejahtera memerlukan keseimbangan peranan keduanya. Jarang sekali ayah dilabel sebagai sumber utama kasih sayang anak-anak. Akibat kurangnya peranan ayah, sang anak akan mendapati banyak risiko negatif, di

\footnotetext{
${ }^{1}$ Ir. Jarot Winarko, M.Pd., Dkk., "Intim Orangtua - Anak", Father and Son Vol. 2. Keluarga Indonesia Bahagia, tt. 7.

${ }^{2}$ Denis Fox \& Isaac Prilleltensy, Psikologi Kritis (Bandung: Teraju, 2005), 192.

${ }^{3}$ Ibid. 202.
} 
antaranya: gangguan kelakuan sosial, peningkatan masalah psikologi, dan kurang keyakinan diri sendiri. ${ }^{4}$

Berdasarkan pemaparan di atas, penelitian ini hendak menjawab suatu permasalahan, yaitu apakah dengan ketiadaan peran ayah berdampak pada psikologis sang anak atau bahkan sang anak tersebut bisa bangkit menjadi lebih mandiri tanpa keberadaan peran ayah? Dari rumusan tersebut, peneliti mencoba lebih dalam mengkaji tentang fatherless terhadap perkembangan anak.

\section{B. Literatur Review}

Pembahasan fatherless dalam jurnal ini juga pernah dibahas dalam jurnal yang lain, seperti penelitian yang dilakukan oleh:

1. Arie Rihardini Sundari dan Febi Herdajani dengan judul Dampak Fatherless terhadap Perkembangan Psikologi anak pada jurnal Universitas Persada Indonesia.

2. Stella Vania Puspitasari dengan judul skripsinya, yaitu Sosok dan Peran Ayah.

3. Setyawati Pambudi Rahardjo, pada acara seminar nasional Universitas Muhammadiyah Purwokerto, dengan tema keterlibatan ayah serta faktorfaktor yang berpengaruh dalam pengasuhan seksualitas sebagai upaya pencegahan perilaku seks pranikah remaja di Purwokerto.

Dari ketiga penelitian di atas, menurut penulis masih belum membahas tentang ketiadaan peran ayah dalam perspektif Islam.

\section{Metodologi Penelitian}

Pengertian kajian pustaka umumnya dimaknai berupa ringkasan atau rangkuman dan teori yang ditemukan dari sumber bacaan ( literatur ) yang ada kaitannya tema yang akan diangkat dalam penelitian. Kajian pustaka merupakan daftar referensi dari semua jenis referensi seperti buku,jurnal papers, artikel, disertasi, tesis, skripsi, hand outs, laboratari manuals, dan karya ilmiah, lainya yang dikutip, dalam penulisan proposal. Kajian pustaka merupakan bahasan atau bahan-bahan bacaan yang terkait dengan suatu topik atau temuan dalam penelitian.

Kajian pustaka merupakan bagian penting dalam sebuah penelitian yang kita lakukan. Sebuah kajian pustaka merupakan sebuah uraian atau deskripsi tentang literatur yang relevan dengan bidang atau topik tertentu sebagaimana ditemukan dalam buku-buku ilmiah dan artikel jurnal. Ia memberikan tinjauan mengenai apa yang telah dibahas atau dibicarakan oleh peneliti atau penulis, teori-teori dan hipotesis yang mendukung, permasalahan penelitian yang diajukan atau ditanyakan, metode dan metodologi yang sesuai. ${ }^{5}$ Untuk itu, penulis mengkajian penelitian ini dengan menggunakan metode kajian pustaka, yaitu kajian yang berpusat pada literasai atau bacaan.

\footnotetext{
${ }^{4}$ dr. Faridah idris., Membesarkan Anak Hebat dengan Susu Ibu (Malaysia: PTS Millenia SDN,
} 2013), 73 .

${ }^{5}$ Setiosary Punaji, Metode Penelitian Pendidikan dan Pengembangan (Jakarta: Kencana, 2010), 22. 


\section{Konsep Dasar Fatherles}

Fatherless atau ketiadaan ayah hakikatnya adalah ketika ayah hanya ada secara biologis namun tidak hadir secara psikologis di dalam jiwa anak. Fungsi ayah lambat laun menjadi dipersempit kepada dua hal yakni: memberi nafkah dan memberi izin untuk menikah. Sementara fungsi pengajaran atau transfer nilai-nilai kebaikan justru hilang yang mengakibatkan anak tak mendapatkan figur ayah dalam dirinya secara utuh.

Lalu, apa penyebab kondisi seperti ini? Munculnya fenomena fatherless lebih banyak dikarenakan paradigma pengasuhan yang dipengaruhi oleh budaya lokal. Paradigma ayah dipengaruhi stereotype budaya bahwa laki-laki itu tak pantas urus anak dan tak boleh terlibat dalam urusan pengasuhan. Sementara tantangan pengasuhan setiap masa semakin bertambah. Ditambah lagi kebutuhan materil masyarakat modern yang makin bertambah yang akibatkan kesibukan bekerja menjadi prioritas hidup demi mengejar segala target yang berkenaan dengan materil. Akhirnya waktu kebersamaan bersama anak berkurang dan cenderung tidak berkualitas.

Apa dampak fenomena fatherless ini bagi perkembangan anak? Dampak dari fatherless adalah kondisi kerusakan psikologis yang disebut dengan father hunger. Hal ini mengakibatkan 7 kondisi yang terjadi kepada anak-anak saat ini di antaranya: ${ }^{6}$

1. Anak cenderung minder dan rendah diri serta sulit adaptasi dengan dunia luar. Sebab keterlibatan ayah dalam mengasuh mempengaruhi cara pandang anak terhadap dunia luar yang membuatnya cenderung lebih kokoh dan berani.

2. Anak memiliki kematangan psikologis yang lambat dan cenderung kekanakkanakan.

3. Anak cenderung lari dari masalah dan emosional saat menghadapi masalah.

4. Kurang bisa mengambil keputusan dan ragu-ragu dalam banyak situasi yang membutuhkan keputusan cepat dan tegas.

Penelitian menyebutkan bahwa keterlibatan aktif ayah dalam pengasuhan anak dapat mendukung perkembangan fisik, kognitif, emosi, sosial, spiritual, dan moral dibandingkan pada anak yang dibesarkan dalam kondisi fatherless. Psikolog Phebe Illenia mengatakan, hendaknya ayah turut berperan dalam pengasuhan terhadap anak, bukan hanya ibu saja. Ayah diharapkan dapat mengelola waktu dengan baik dan memaksimalkan kualitas interaksi dengan anak. ${ }^{7}$

\section{E. Diskusi Peran Ayah dalam Preskpektif Pendidikan Islam}

Dalam Islam, peran Ayah begitu penting. Ia tidak hanya seorang imam tetapi juga pendidik. Yang namanya pendidik berarti bisa mencakup segala hal, baik pikiran, emosi, maupun perilakunya. Jadi, baik dan buruknya keluarga, terutama anaknya, itu tergantung kepala keluarganya, yang tak lain adalah sang ayah. oleh sebab itu, seorang ayah punya tanggung jawab besar bagi anaknya.

\footnotetext{
${ }^{6} \mathrm{http}: / /$ mommee.org/mengenal-fenomena-fatherless/

${ }^{7}$ https://www.jawapos.com/read/2017/05/09/128845/ini-peran-ayah-yang-ideal-untuk-keluarga
} 


\section{Mempersiapkan Anak sebagai hamba (Abdan) dan Khalifah}

Ada dua kata kunci dalam Islam bahwa manusia dibebankan dalam hidupnya adalah sebagai hamba dan khalifah. Dua amanat ini mesti dipikul oleh manusia di sepanjang hidupnya. Ayah punya tugas untuk membimbing anaknya sejak kecil, agar menjadi hamba sekaligus khalifah yang baik. Allah SWT sudah mewanti-wanti hal ini agar seorang ayah mempersiapkan anak-anaknya agar benar-benar menjadi hamba sekaligus khalifah yang baik.

Hamba dan khalifah yang baik itu yang bagaimana? Jawabannya adalah dalam ayat sebagai berikut:

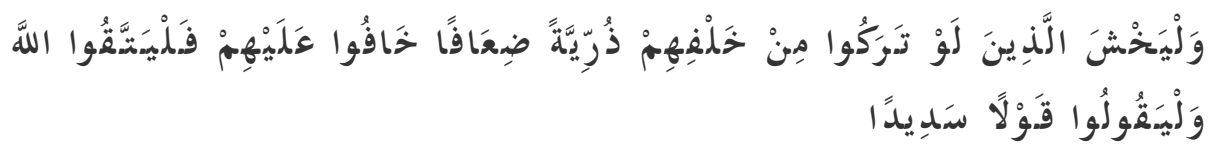

"Dan hendaklah takut kepada Allah, orang-orang yang seandainya meninggalkan di belakang mereka anak-anak yang lemah, yang mereka khawatir akan kesejahteraan mereka. Oleh sebab itu hendaklah mereka bertakwa kepada Allah dan hendaklah mereka mengucapkan perkataan yang benar" (QS. An-Nisa [4] : 9).

Rasa takut kepada Allah SWT itulah yang mesti dipunyai seorang ayah, karena dengan punya rasa takut itu akan menjaga anak-anaknya dengan serius. Ketakutan itu diisi dengan takwa kepada Allah SWT dan berucap benar. Takwa artinya melaksanakan perintah Allah dan menjauhi larangan-Nya. Hal ini berarti mengajarkan anaknya untuk melaksanakan segala perintah Allah SWT dan menjauhi segala larangan-Nya.

Sedang perkataan yang benar artinya mengajarkan kejujuran kepada anaknya. Jika tidak, sang anak akan terbiasa dengan kebohongan. Perkataan jujur dan benar adalah hal dasar yang menentukan kepada segala hal.

Hamka menafsirkan kata qaulan sadida bermakna ucapan yang tepat yang timbul dari hati yang bersih, sebab ucapan adalah gambaran dari apa yang ada di dalam hati. Orang yang mengucapkan kata-kata yang dapat menyakiti orang lain menunjukkan bahwa orang tersebut memiliki jiwa yang tidak jujur.

Melihat dari pesan moral kisah di atas, betapa kejujuran menjadi nilai pertama yang dilihat. Apabila kejujuran tidak dilaksanakan sejak kecil maka akan merambat kepada perilaku pada saat remaja dan dewasa. Fenomena rusaknya moral remaja dan dewasa tidak bisa dilepaskan pada saat masa kanak-kanaknya akan pentingnya kejujuran.

\section{Ayah sebagai Pemimpin (Leader)}

Islam menempatkan Ayah sebagai pemimpin dalam keluarga, seperti disebutkan dalam hadis berikut ini.

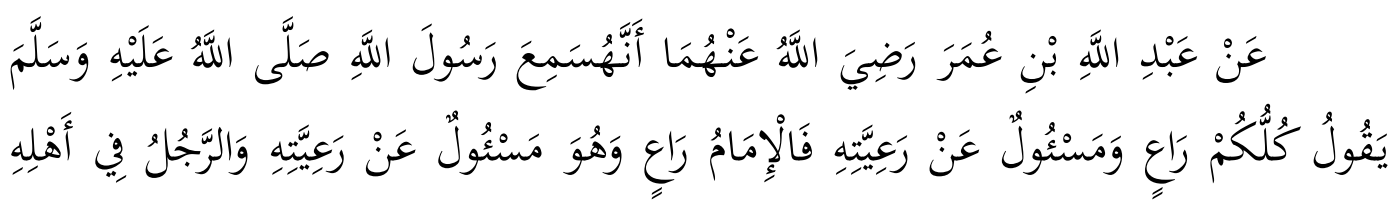




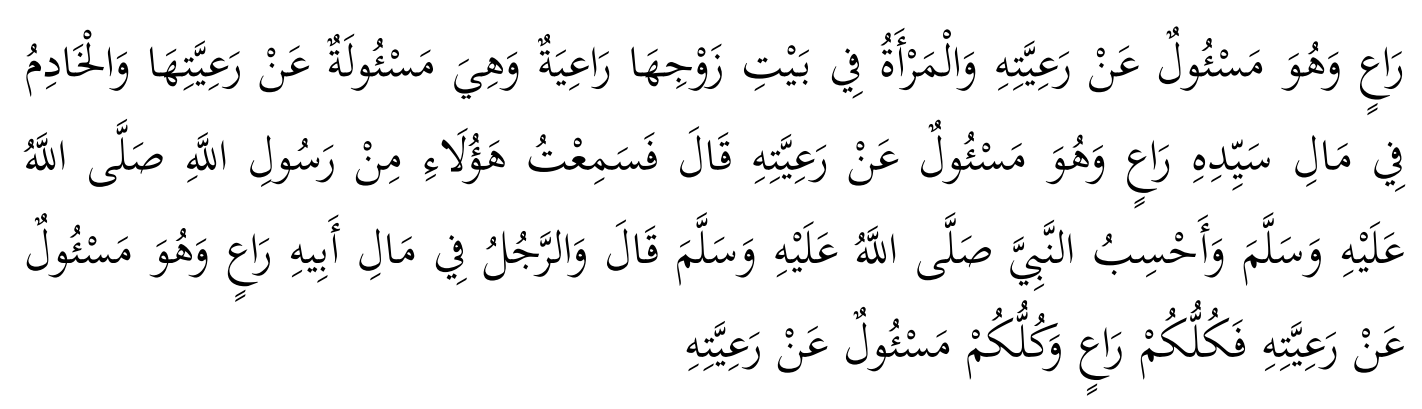

Dari 'Abdullah bin 'Umar r.a. bahwa dia mendengar Rasulullah Saw. telah bersabda: "Setiap kalian adalah pemimpin dan setiap pemimpin akan diminta pertanggungjawaban atas yang dipimpinnya. Imam (kepala Negara) adalah pemimpin yang akan diminta pertanggungjawaban atas rakyatnya. Seorang suami dalam keluarganya adalah pemimpin dan akan diminta pertanggungjawaban atas keluarganya. Seorang istri adalah pemimpin di dalam urusan rumah tangga suaminya dan akan diminta pertanggungjawaban atas urusan rumah tangga tersebut. Seorang pembantu adalah pemimpin dalam urusan harta tuannya dan akan diminta pertanggungjawaban atas urusan tanggung jawabnya tersebut." Dia ('Abdullah bin 'Umar r.a.) berkata: "Aku mendengar semua itu dari Rasulullah Saw. dan aku menduga Nabi juga bersabda", "Dan seorang laki-laki pemimpin atas harta bapaknya dan akan diminta pertanggungjawaban atasnya dan setiap kalian adalah pemimpin dan setiap pemimpin akan diminta pertanggung jawaban atas yang dipimpinnya." (HR Bukhari)

Dalam hadis di atas begitu gamblang perihal tanggung jawab seorang suami yang mencakup berbagai sisi dalam keluarga. Ia tidak hanya bertanggung jawab mencari nafkah tetapi juga dalam hal lainnya, seperti mengasuh anak, mengasihi anak dan istrinya, serta mendidiknya. Segalanya ada di dalam tanggung jawab seorang suami.

Dalam Islam, kepemimpinan seorang suami begitu penting. Arah angin keluarga tergantung nakhodanya, yaitu suami. Ia berkewajiban membina perilaku dan karakter para awaknya yaitu istri dan anaknya. Yang dibina tidak hanya soal moral tetapi juga iman. Tidak hanya sosial dan emosional, tetapi juga spiritual. Itulah kelebihan dalam Islam.

Seorang suami harus bisa membekali keluarganya yang tidak hanya bekal untuk di dunia tetapi juga di akhirat. Dalam arti bahwa seorang suami harus visioner, menatap jauh ke depan pada saat membimbing anggota keluarganya. Ia mengajarkan anaknya bukan saja keterampilan (skill), tetapi juga moral dan spiritual.

Seorang pemimpin keluarga harus bertanggung jawab dan bijaksana untuk membawa dan mengarahkan keluarganya ke jalan yang lebih baik. Ia harus menjadi suri teladan yang tidak hanya memerintah dan membimbing anaknya tetapi juga memberi contoh konkrit.

Jika menginginkan anaknya shaleh, berbuat baik pada siapa pun, berkatakata sopan, dan rajin beribadah, maka ayahnya harus terlebih melakukan hal 
demikian. Tantangan masa kini sungguh tidak mudah bagi seorang ayah. Era internet ibarat dua sisi mata uang, ia bisa mencelakai tetapi juga bisa memberikan manfaatnya. Di sinilah peran seorang pemimpin harus mampu bersikap apa yang mesti dilakukan terhadap anaknya.

Dalam Islam, hal yang paling ditekankan adalah keimanan dan akhlak. Oleh karena itu betapa pentingnya seorang ayah menanamkan keimanan dan akhlak kepada anaknya. Karena bagaimana pun anak adalah penerus ayahnya dalam hal keimanan kepada Allah SWT. Estafet Islam terus dilakukan turun temurun, sehingga ajaran Islam terus terpelihara di dunia ini.

Jadi keimanan dalam diri anak tidak muncul begitu saja. Ia harus dipupuk sejak dini. Hal itu bisa dilakukan dengan cara, misalnya, memberikan kisah-kisah tentang para nabi, para sahabat, dan orang-orang shaleh, yang beriman dan bertakwa kepada Allah SWT.

\section{Ayah sebagai Pendidik (Educator)}

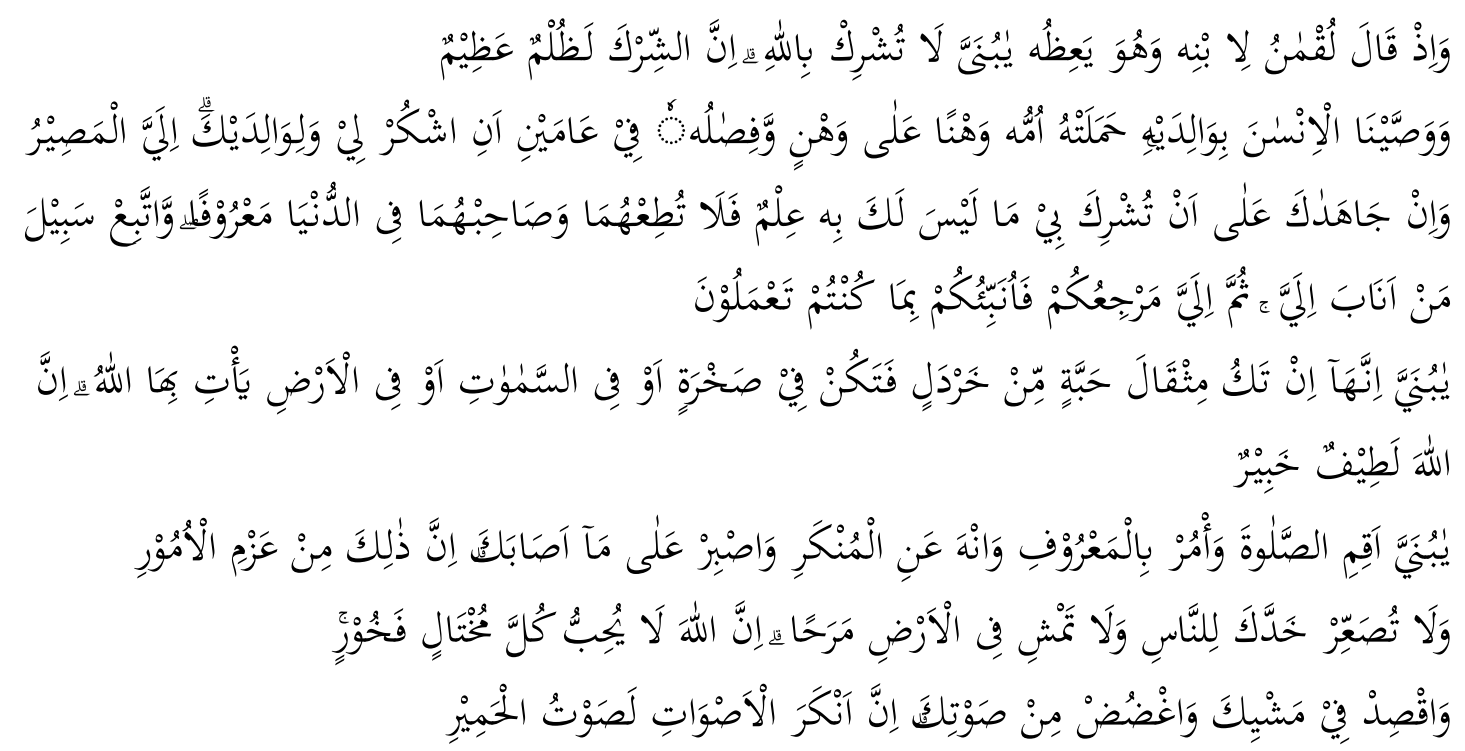

Dan (ingatlah) ketika Luqman berkata kepada anaknya, di waktu ia memberi pelajaran kepadanya: "Hai anakku, janganlah kamu mempersekutukan Allah, sesungguhnya mempersekutukan (Allah) adalah benar-benar kezaliman yang besar". Dan Kami perintahkan kepada manusia (berbuat baik) kepada dua orang ibu-bapaknya; ibunya telah mengandungnya dalam keadaan lemah yang bertambah- tambah, dan menyapihnya dalam dua tahun, bersyukurlah kepadaku dan kepada dua orang ibu bapakmu, hanya kepada-Kulah kembalimu. Dan jika keduanya memaksamu untuk mempersekutukan dengan aku sesuatu yang tidak ada pengetahuanmu tentang itu, maka janganlah kamu mengikuti keduanya, dan pergaulilah keduanya di dunia dengan baik, dan ikutilah jalan orang yang kembali kepada-Ku, kemudian hanya kepada-Kulah kembalimu, maka Kuberitakan kepadamu apa yang telah kamu kerjakan. (Luqman berkata): "Hai anakku, Sesungguhnya jika ada (sesuatu perbuatan) seberat biji sawi, dan berada dalam batu atau di langit atau di dalam bumi, niscaya Allah akan mendatangkannya (membalasinya). Sesungguhnya Allah Maha Halus lagi Maha 
mengetahui. Hai anakku, dirikanlah shalat dan suruhlah (manusia) mengerjakan yang baik dan cegahlah (mereka) dari perbuatan yang mungkar dan bersabarlah terhadap apa yang menimpa kamu. Sesungguhnya yang demikian itu termasuk hal-hal yang diwajibkan (oleh Allah). Dan janganlah kamu memalingkan mukamu dari manusia (karena sombong) dan janganlah kamu berjalan di muka bumi dengan angkuh. Sesungguhnya Allah tidak menyukai orang-orang yang sombong lagi membanggakan diri. Dan sederhanalah kamu dalam berjalan dan lunakkanlah suaramu. Sesungguhnya seburuk-buruk suara ialah suara keledai."(QS. Luqman ayat 13-19).

Ayat di atas menyiratkan bahwa seorang ayah juga pemimpin sekaligus pendidik bagi anaknya. Ia tidak dapat melepaskan masalah pendidikan anakanaknya hanya kepada ibu dan sekolahnya. Anak memerlukan ayah dalam perkembangannya, yang tidak dapat digantikan.

Dalam beberapa hadits shahih juga disebutkan antara lain riwayat AtThabrani bahwa Nabi Muhamad SAW bersabda, "Didiklah anak-anakmu dengan tiga perkara: mencintai Nabimu; mencintai ahlul baitnya; dan membaca AlQur'an, karena orang-orang yang memelihara Al-Qur'an itu berada dalam lingkungan singgasana Allah pada hari ketika tidak ada perlindungan selain dari pada perlindungan-Nya; mereka beserta para Nabi-Nya dan orang-orang suci."

Menjalankan peran dan tanggungjawabnya sebagai pendidik atau edukator, seorang Ayah adalah guru bagi anak-anaknya, baik di dalam maupun di luar rumah. Cakupan pendidikan yang bisa diberikan pada anaknya begitu luas. Tidak hanya masalah kognitif tetapi juga afektif, bahkan spiritual. Bukan hanya pendidik dalam hal akademik saja tetapi juga sosial dan nilai-nilai agama.

Bagaimanapun, seorang ayah, menurut Bloir, dapat berperan penting bagi perkembangan pribadi anak, baik sosial, emosional maupun intelektualnya. Pada diri anak akan tumbuh motivasi, kesadaran dirinya, dan identitas skill serta kekuatan/ kemampuan-kemampuannya sehingga memberi peluang untuk sukses belajarnya, identitas gender yang sehat, perkembangan moral dengan nilainya dan sukses lebih primer dalam keluarga dan kerja/kariernya kelak. Terhadap semua itu pengaruh peran ayah yang paling kuat adalah terhadap prestasi belajar anak dan hubungan sosial yang harmonis. ${ }^{8}$

Rasulullah telah membuatkan metode yang jelas dalam rangka mencegah kesalahan-kesalahan pada anak serta meluruskan ketimpangan perilaku mereka. Orangtua yang berperan sebagai pendidik semestinya menempuh metode yang diberikan Rasulullah dan memilih metode yang paling patut dipakai dalam mendidik dan mengasuh anak ,sehingga para orangtua sampai pada apa yang mereka cita-citakan yaitu mendapatkan anak yang disiplin, beriman dan bertakwa.

Di antara metode Rasulullah dalam mencegah atau mengatasi kesalahan ialah pengarahan langsung. Imam Bukhari dan Muslim meriwayatkan hadis dari Abu Salamah, ia berkata, "Aku pernah di bawah asuhan Rasul, dan waktu itu tanganku menggamak ke sana - sini di dalam baskom besar, maka Rasul berkata

\footnotetext{
${ }^{8}$ Bloir, K. 2002, What About Dad?. http://ohioline.osn.edn/ hygfact/5000/5155.htm/. (11/23/02)
} 
kepadaku, "Wahau anakku, bacalah bismillah kemudian makanlah dengan tangan kananmu, dan makan makanlah yang dekat denganmu". 9

\section{F. Kesimpulan}

Berdasarkan pemaparan di atas, dapat disimpulkan bahwa keberadaan ayah secara fisik dan psikis sangat mempengaruhi perkembangan anak, dimana dampaknya terhadap anak, yaitu:

1. Anak cenderung minder dan rendah diri serta sulit adaptasi dengan dunia luar. Sebab keterlibatan ayah dalam mengasuh mempengaruhi cara pandang anak terhadap dunia luar yang membuatnya cenderung lebih kokoh dan berani.

2. Anak memiliki kematangan psikologis yang lambat dan cenderung kekanakkanakan

3. Anak cenderung lari dari masalah dan emosional saat menghadapi masalah

4. Kurang bisa mengambil keputusan dan ragu-ragu dalam banyak situasi yang membutuhkan keputusan cepat dan tegas.

Karena peran ayah sebagai pemimpin dan pendidik tidak ada, padahal dari kedua peran tersebut ayah bisa mempersiapkan anaknya sebagai abdan dan khalifah.

\section{DAFTAR PUSTAKA}

Bloir, K. 2002. What About Dad?. http://ohioline.osn.edn/ hygfact/5000/5155.htm/. $(11 / 23 / 02)$

Fox, Denis \& Isaac Prilleltensy. 2005. Psikologi Kritis. Jakarta: Teraju.

http://mommee.org/mengenal-fenomena-fatherless/

https://www.jawapos.com/read/2017/05/09/128845/ini-peran-ayah-yang-ideal-untukkeluarga

Idris, Faridah. Membesarkan Anak Hebat dengan Susu Ibu, PTS Millenia SDN: Malaysia.

Muhammad, Abdul Mu'thi. 2004. Kiat-Kiat Menjadi Ayah yang Berhasil, Abdullah Muhammad Abdul Mu'thi. Penj. Khairun Naim, Qisthi Press,.

Winarko, Jarot, dkk. tt. "Intim Orangtua - Anak", Father and Son Vol. 2. Keluarga Indonesia Bahagia,.

Punaji, Setiosary. 2010. Metode Penelitian Pendidikan dan Pengembangan. Jakarta: Kencana.

9 Abdullah Muhammad Abdul Mu'thi, Kiat-Kiat Menjadi Ayah yang Berhasil. Penj. Khairun Naim, (Jakarta: Qisthi Press, 2004), 139. 